\title{
AGAMA DAN NEGARA : RELEVANSI AGAMA ISLAM DENGAN NEGARA
}

\section{Oleh : Fatoni Achmad}

\begin{abstract}
As social human beings interact and communicate with each other. In the interaction and social communication is needed a regulations that regulate all sides of life in order to create a comfortable and conducive environment. The State is a container organization in a region gives clear rules to its people by forming a common and shared vision that is as stated in the noble values of Pancasila, this is no exception to Islam in which contains the rules that can be a guide and the foundation the basis for living a good life both in the world and in the akherat. Society needs to understand the importance of the values contained in religion and the state as a form of embodiment towards the ideals of the nation, which ultimately requires the community to learn and explore what religion and state in all things and how the relevance between them.
\end{abstract}

Key Word: Relevance, religion, Islam, State

\section{A. Pendahuluan}

Sebagai makhluk social manusia berinteraksi dan berkomunikasi antara yang satu dengan lainnya. Dalam interaksi dan komunikasi social inilah dibutuhkan suatu peraturan-peraturan yang mengatur semua sisi kehidupan agar tercipta lingkungan yang nyaman dan kondusif. Dalam hal negara merupakan wadah organisasi dalam suatu wilayah memberikan aturan yang jelas kepada rakyatnya dengan membentuk satu visi yang sama dan bersama yakni seperti yang tertuang pada nillai-nilai luhur Pancasila, ini tidak terkecuali agama Islam yang didalamnya termuat peraturan-peraturan yang dapat menjadi pedoman dan landasan dasar untuk menjalani hidup yang selamat baik di dunia maupun di akherat.

Masyarakat perlu memahami akan pentingnya nilai-nilai yang terkandung dalam agama dan negara sebagai bentuk perwujudan menuju cita-cita bangsa, yang pada akhirnya menuntut masyarakat untuk belajar dan mendalami apa itu agama dan negara dalam segala hal dan bagaimana relevansi antara keduanya.

\section{B. Konsep Agama Islam}

\section{Pengertian Agama}

Dalam kamus besar bahasa Indonesia kata agama mempunyai artikan sebagai ajaran, sistem yg mengatur tata keimanan (kepercayaan) dan peribadatan kepada 
Tuhan Yang Maha kuasa serta tata kaidah yg berhubungan dengan pergaulan manusia dan manusia serta lingkungannya. ${ }^{1}$

Menurut Harun Nasution dan Muh. Said kata agama berasal dari bahasa sanskerta. Kata agama tersusun dari dua kata yaitu "A" yang mempunyai arti "tidak" dan Gama yang bermakna berubah atau berjalan. Dengan demikian dapat disimpulkan bahwa agama merupakan tidak pergi atau diam pada tempatnya. ${ }^{2} \mathrm{Hal}$ ini senada dengan kata gama yang diartikan sebagai tidak kacau yang apabila di uraikan dengan cara memisahkan kata agama tersebut menjadi kata perkata yaitu "A" berarti tidak dan "Gama" yang artinya kacau, maksudnya adalah seseorang yang dalam kehidupannya menjadikan agama sebagai pedoman hidup dan bersungguh-sungguh dalam mengamalkan ajaran-ajaran yang telah diberikan oleh agama maka kehidupanya akan menjadi tidak kacau (Sejahtera). ${ }^{3}$

Sejauh saat ini belum ada definisi agama secara umum, namun ditinjau dari segi historis kata agama seringkali dihubungkan dengan hal-hal yang bersifat sacral yang didalamnya terdapat praktek-praktek pemujaan. Praktek pemujaan inilah yang menjadi penghubung antara manusia dengan sesuatu yang disembah, dipuja, dan dianggap mempunyai kebenaran dan kekuasaan secara mutlak selanjutnya melahirkan suatu tatanan atau perintah untuk melaksanakan atau meningalkan. Mendefinisikan agama memanglah tidak mudah karena dalam agama bersifat bathiniyah, subjektif, dan individualistis meskipun agama mempunyai nilai-nilai yang bersifat universal.

Menurut frazer agama merupakan suatu tindakan dalam upaya mendamaikan manusia dengan cara mengatur dan mengontrol kehidupan manusia dalam melangsungkan hidupnya di muka bumi. ${ }^{4}$ Sedangkan Harun Nasution secara simplistic mendefinisikan agama seolah hendak menyamakan begitu saja antara pengertian konsep agama, din, dan religi. Ia menarik benang merah antara ketiga konsep tersebut dengan menyimpulkan bahwa intisari yang terkandung dalam istilah agama, din, dan religi mengerucut pada makna yang sama yaitu berupa ikatan-ikatan yang harus dipegang dan dipatuhi manusia. Ikatan-ikatan inilah yang, dalam

\footnotetext{
${ }^{1}$ Software Kamus Besar Bahasa Indonesia, Version 1.5. 1 Offline

${ }^{2}$ Aflatun Muchtar, Tunduk Kepada Allah Fungsi Dan Peran Agama Dalam Kehidupan Manusia, Khazanah Baru, Jakarta 2001, hlm.22

${ }^{3}$ Sukardji, Agama-agama yang berkembang di dunia dan pemeluknya, Bandung:Angkasa,1993, hlm 26.

${ }^{4}$ Ibrahim Gultom, Agama Malim Di Tanah Batak, PT.Bumi Aksara, Jakarta : 2010, hlm.17
} 
pandangan Harun Nasution, memberikan pengaruh bagi kehidupan sehari-hari manusia. $^{5}$

Kata agama dalam bahasa inggris disebut dengan religion, Bozman dalam anshari mengartikan agama secara luas yakni penerimaan aturan-aturan dari kekuatan yang lebih tinggi, dengan cara melakukan pendekatan-pendekatan yang baik dan harmonis dengan realitas yang lebih agung dari dirinya sendiri baik dengan cara pelayanan maupun pengabdian kepadanya. ${ }^{6}$ Friedrich Schleiermacer, menegaskan bahwa agama tidak dapat di lacak dari pengetahuan rasional, juga tidak dari tindakan moral, akan tetapi agama berasal dari perasaan ketergantungan mutlak kepada yang tak terhingga (feeling of absolute dependence). ${ }^{7}$

Agama secara terminologi dalam ensiklopedia Nasional diartikan sebagai peraturan yang mengatur tentang hubungan manusia dengan Tuhan sekaligus sesama manusia. Sedangkan agama dalam Al Qur'an disebut dengan din. Istilah din merupakan bawaan dari ajaran Islam dan secara makna bersifat universal, artinya konsep din seharusnya dapat mengakomodir dari seluruh makna agama dan religi itu sendiri. Harun Nasution menjelaskan konsep agama adalah sebagi berikut, dalam bahasa arab agama disebut al-din. dengan panjang mad pada "diin”, yang mempunyai beberapa arti yaitu:
a. Sistem atau cara,
b. Paksaan, kekuatan, dan tekanan
c. Ketaatan, kepatuhan atau peribadatan.
d. Pembalasan atau perhitungan. ${ }^{8}$

Semua agama paling tidak mempunyai empat ciri khas. Pertama, aspek doktrin, yaitu ajaran dogmatis yang harus diyakini dan dipatuhi. Kedua, aspek ibadah (ritual), yaitu aturan yang mengatur hubungan dengan Tuhan untuk menunjukkan pengabdian dan kesetiaan. Ketiga, aspek moral, yaitu ajaran tentang aturan

\footnotetext{
${ }^{5}$ Harun Nasution, Islam Ditinjau dari Berbagai Aspeknya, Jilid I, Cetakan V, Jakarta: Penerbit Universitas Indonesia, 1985, hlm. 10

${ }^{6}$ Endang Saifuddin Anshari, Kuliah Al-Islam, Pusataka Bandung, 1978, hlm. 46.

${ }^{7}$ Jalaluddin Rakhmat, Psikologi Agama sebuah pengantar, Bandung: PT. MIizan Pustaka, 2004, hlm. 2022

${ }^{8}$ Harun Nasution, Islam Ditinjau dari Berbagai Aspeknya, Jilid I, Cetakan V, Jakarta: Penerbit Universitas Indonesia, 1985, hlm. 98
} 
berperilaku dan bertindak yang benar dan baik bagi inidividu dalam kehidupan. Keempat, aspek social, ajaran yang mengatur tentang bagaimana harus hidup bersama dengan masyarakat. ${ }^{9}$

Agama-agama yang tumbuh dan berkembang di bumi dapat dklasifikasn kedalam dua kelompok berdasarkan asal muasalnya : Pertama, agama langit (samawi) yaitu agama yang dihasilkan atau diperoleh melalui wahyu Allah. Kedua, agama bumi (ardli) yaitu agama yang yang dibangun berdasarkan kreatifitas manusia. Menurut Abudin Nata agama mempunyai beberapa unsur antara lain :

a. Pertama, kepercayaan terhadap kekuatan ghaib. Dalam kepercayaan primitive kekuatan ghaib tersebut muncul dari benda yang dianggap keramat dan mempunyai nilai yang sacral serta mempunyai kekuatan yang bersifat mistik, ruh, jiwa.

b. Kedua, pola hubungan terhadap kepercayaan adanya kekuatan ghoib yang telah dijelaskan pada point pertama akan berimplikasi pada kebahagiaan dan kesejahteraan hidup manusia selanjutnya.

c. Ketiga, respons manusia yang emosional dalam ritualyang dapat menimbulkan rasa takut, bersalah, dan menyembah yang pada akhirnya berpengaruh pada cara hidup masyarakat yang bersangkutan.

d. Keempat, adanya peraturan berupa kitab yang mengatur tentang bagaimana ritual yang sedang dan akan dilaksankan. ${ }^{10}$

\section{Islam}

Dalam Kamus Besar Bahasa Indonesia kata Islam mempunyai arti agama yang diajarkan oleh Nabi Muhammad SAW berpedoman pada kitab suci Al Qur'an yang diturunkan ke dunia melalui wahyu Allah SWT. ${ }^{11}$ Sedangkan kata Islam itu sendiri berasal dari kata "aslama-yuslimu-islaman" yang mempunyai makna keselamatan, kesejahteraan, kedamaian, dan pasrah. Menurut Hammudah Abdalati kata "Islam" berasal dari akar kata Arab yang tersusun dari beberapa huruf yaitu : Sin, Lam, dan Mim yang berarti kedamaian, kesucian, penyerahan diri,

\footnotetext{
${ }^{9}$ Tim Dosen Pendidikan Agama Islam MKDU UPI, 2008, hlm. 12
}

${ }^{10}$ Abuddin Nata, Metodologi Study Islam, Jakarta, PT. Raja Grafindo Persada, 1999, cet. Ke-3, hlm. 14 
dan ketundukkan. ${ }^{12}$ Senada dengan pernyataan tersebut, dalam literature lain dikatakan bahwa Islam berasal dari bahasa Arab yang diambil dari kata "salima" yang mempunyai arti selamat sentosa. Dari asal kata itulah terbentuk kata "aslama" yang maknanya memelihara keadaan yang selamat sentosa, yang dalam hal ini berarti pula menyerahkan diri, tunduk, patuh, dan taat. Kata "Aslama" inilah menjadi sumber dari terbentuknya semua kata yang seakar dengan Islam dan umat manusia yang memeluk agama atau ajaran Islam disebut dengan muslim. Orang yang memeluk agama Islam berarti sudah menyerahkan segala hidupnya dan patuh serta tunduk terhadap aturanaturan yang telah ditetapkanNYA. ${ }^{13}$ oleh sebab itu seseorang yang patuh, tunduk dan berserah diri serta taat dinamakan sebagai seorang muslim. Orang yang demikian berarti telah menyatakan dirinya taat, menyerahkan diri dan patuh kepada Allah SWT yang selanjutnya orang tersebut akan dijamin keselamatannya baik didunia maupun di akhirat. $^{14}$

Salah satu yang menjadikan orang salah dalam memahami ajaran Islam disebabkan karena visi yang kurang tepat dalam memandang ruang lingkup ajaran Islam serta penggambaran hanya bersifat parsial dan tidak universal dari seluruh ajaran Islam. Menurut Vera Micheles Dean dalam karyanya “ The Nature of The Non Western World" sebagaimana yang dikutip oleh Humaidi bahwa islam setidaknya meliputi beberapa unsur di antaranya :

a. Islam is religion (Islam adalah Agama)

b. Islam is political system(Islam adalah Sistem Politik)

c. Islam is way of live (Islam adalah Pandangan Hidup)

d. Islam is interpretation of history(Islam adalah interpretasi sejarah) ${ }^{15}$

Islam merupakan suatu system yang integral dan universal yang didalamnya memuat unsur-unsur kepercayaan dan ritual yang menyangkut kehidupan manusia, oleh sebab itu dalam mewujudkan system tersebut perlu dirumuskan visi yang tepat dan benar untuk menghindari kesalahan dalam rangka menuju kesempurnaan.

\footnotetext{
${ }^{12}$ Hammudah Abdalati, Islam in Focus, American Trust Publications Indianapolis-Indiana, 1975, hlm. 7.

${ }^{13}$ Drs. Nasruddin Razak, Dienul Islam, Al-Ma'arif Bandung, 1989, hlm. 56-57

${ }^{14}$ Abuddin Nata, Metodologi Study Islam, Jakarta, PT. Raja Grafindo Persada, 1999, cet. Ke-3, hlm. 62

${ }^{15}$ Humaedi Tata Pangarsa, Kuliah Akidah Lengkap, Surabaya: PT. Bina Ilmu, 1981, cet. ke-5, hlm. 36-44
} 
Demikian pula untuk menjadikan Islam sebagai sistem hidup harus berangkat dari visi yang tepat dan benar.

Ending Saifuddin Anshari merumuskan dan menyimpulkan pengertian Islam sebagai berikut :

1. Islam merupakan wahyu Allah yang diturunkan melalui malaikat jibril kepada nabi Muhammad SAW untuk disampaikan kepada seluruh umat manusia yang ada di muka bumi.

2. Suatu system yang mengatur kehidupan manusia mulai dari hubungan manusia dengan Tuhan "Hablu MinaAlla", hubungan manusia dengan manusia "Hablu Minan Naas", hubungan manusia dengan 'alam "Hablu Minal "alam”.

3. Islam difungsikan sebagai jalan menuju kebahagiaan baik di dunia maupun di akherat dalam rangka mencari ridlo dan rahmat Allah SWT.

4. Kajian Islam meliputi Akidah, syari'ah dan akhlak.

5. Islam mempunyai kitab suci yang menjadi pedoman hidup seluruh umat yaitu Al Quran yang merupakan wahyu Allah sekaligus penyempurna kitab-kitab sebelumnya. ${ }^{16}$

Dari penjelasan di atas dapat dipahami bahwa agama Islam merupakan agama yang berasal dari Allah SWT yang kerangka dan ketentuannya telah ditetapkan olehNYA dan Al Qur'an sebagai wahyu Allah yang dijadikan pedoman manusia dalam menajalani hidup. Adapun peraturan - peraturan Agama Islam meliputi, Hablu MinaAllah (Hubungan dengan Allah), Hablu Minan Nas (Hubungan dengan Manusia) dan Hablu Minal 'Alam (Hubungan dengan Alam) yang dalam hal ini bertujuan untuk menghantarkan manusia pada jalan yang benar selamat baik dunia maupun akherat.

3. Konsep Negara

Dinjau dari segi bahasa Kata negara merupakan bentuk terjemahan dari beberapa kata asing antara lain :

a. Dari bahasa Belanda dan Jerman kata Negara disebut dengan "Staat"

\footnotetext{
${ }^{16}$ Endang Saifuddin Anshari, Kuliah Al-Islam, Pusataka Bandung, 1978, hlm. 46.
} 
b. Dari bahasa Inggris kata negara disebut "State"
c. Dari bahasa Perancis kata negara disebut "Etat"

Dari ketiga kata tersebut staat, state, dan etat diambil dari bahasa latin yaitu "status" atau "statum" yang artinya keadaan tegak dan tetap atau bisa juga sesuatu yang mempunyai sifat yang tetap dan tegak. Sedangkan menurut terminologi, negara dapat diartikan sebagai organisasi tertinggi di antara satu kelompok masyarakat yang hidup di dalam suatu kawasan dan mempunyai pemerintahan yang berdaulat serta yang memiliki cita-cita dan tujuan yang sama. Pengertian negara demikian ini mengandung nilai konstitutif pada umumnya dimiliki oleh suatu negara yang berdaulat: masyarakat sebagai (rakyat), wilayah sebagai kekuasaan, dan pemerintahan yang berdaulat sebagai aturan yang harus ditaati. lebih lanjut pengertian negara di atas, indentik dengan hak dan wewenang. ${ }^{17}$

Negara merupakan suatu organisasi yang didalamnya terdapat unsur paksaan atas kekuasaan yang secara sah terhadap suatu golongan lain dan adanya tujuantujuan hidup bersama yang ditetapkan dengan cara dan batas-batas sejauh kekuasaan itu dapat digunakan dalam kehidupan bersama, baik individu, komunitas maupun asosiasi serta oleh negara itu sendiri. ${ }^{18}$ Senada dengan pengertian negara di atas yaitu negara merupakan suatu masyarakat yang memonopoli dalam penggunaan kekerasan fisik yang secara sah dalam suatu wilayah. ${ }^{19}$ Dengan demikian dapat dikatakan bahwa negara merupakan suatu daerah territorial yang dalam hal ini rakyatnya diperintah oleh sejumlah pejabat yang mempunyai otoritas akan kekuasaanya, serta menjadikan warga negaranya taat dan patuh terhadap undang-undang sebagai control yang sah akan monopolinya. ${ }^{20}$

Dalam pengertian negara di atas dapat dijelaskan bahwa negara merupakan suatu organisasi kelompok manusia yang mempunyai tata peraturan sebagai control

\footnotetext{
${ }^{17}$ Ubaedillah dan Abdul Rozak dkk, Pendidikan Kewarganegaraan, Demokrasi, HAM dan Masyarakat Madani, (ICCE UIN Syarif Hidayatulla: Jakarta, Edisi ke-3, 2008) hal. 84

${ }^{18}$ Dede Rosyada, Pendidikan Kewarganegaraan Demokrasi, HAM, dan Masyarakat Madani, Jakarta: IAN Jakarta Press, 2000, hlm, 31-33.

${ }^{19}$ Budiyanto. Dasar-dasar Ilmu Tata Negara untuk SMU. Jakarta : Erlangga, 2000.

${ }^{20}$ Miriam Budiarto, Dasar-dasar Ilmu politik, Jakarta: Gramedia Pustaka Media, 1978, hlm. 39-40.
} 
atas wilayah kekuasaannya untuk mewujudkan cita-cita dan tujuan bersama yang sudah ditetapkan. Organisasi disini yang dimaksud bukanlah hanya satu organisasi saja melainkan terdiri dari berbagai organisasi yang ada dalam wilayah kekuasaan negara, beberapa organisasi tersebut antara lain: keagamaan, partai, kemasyarakatan, dan organisasi independen yang terlepas dari masalah kenegaraan. Dengan demikian negara secara umum dapat dipahami sebagai suatu organisasi yang utama yang ada dalam suatu wilayah, karena negara mempunyai kuasa penuh atas control dari semua organisasi-organisasi yang ada dalam suatu wilayah tertentu. Dalam pembentukan suatu negara ada beberapa elemem yang harus ada, antara lain :

a. Masyarakat

Masyarakat merupakan elemen terpenting dalam suatu negara, karena tanpa adanya masyarakat tentu suatu negara tidak akan ada. Masyarakat dalam suatu negara berserikat kemudian menjadi rakyat yang mempunyai kepentingan dalam mensukseskan tata-pemerintahan. Betapa pentingnya elemen masyarakat ini tidak hanya menyangkut masalah negara saja tetapi banyak ilmu yang bergantung kepadanya termasuk di antaranya adalah ilmu sosiologi, yaitu suatu ilmu yang khusus mempelajari dan menyelidiki tentang pola hidup manusia dalam bermasyarakat. Selain itu, ilmu sosiologi merupakan bagian dari ilmu ketatanegaraan.

b. Wilayah

Negara tidak dapat berdiri tanpa adanya wilayah. Wilayah menjadi batas yang jelas bagi berlangsungnya hidup masyarakat dalam suatu negara. Selain dari pentingya unsur wilayah dengan batas yang jelas, penting pula keadaan wilayah tersebut, artinya layak atau tidak suatu wilayah untuk masuk dalam suatu negara atau sebaliknya menjadi bagian negara lainnya. Undang-undang atau peraturan yang dibuat suatu wilayah bersifat sectoral maksudnya hanya berlaku pada wilayah tersebut. Dengan demikian orang akan segera sadar akan peraturanperaturan yang mengikat pada suatu wilayah itu dan memenuhi kewajiban sebagai rakyat yang taat.

Menurut Paul Renan yang menjadi ukuran dalam masyarakat untuk menjadi suatu negara adalah dengan cita-cita dan tujuan yang sama (bersatu atau 
le desir de'etre ansemble). Sedangkan Otto Bauer menyatakan bahwa ukuran tersebut diletakkan pada keadaan khusus dari wilayah dalam satu negara.

c. Pemerintahan

Dalam suatu negara pemerintahan mempunyai kekuasaan yang sah atas semua anggota masyarakat dalam hal ini rakyat yang merupakan penduduk dalam suatu wilayah negara. Dalam menjalankan roda pemerintahan negara mempunyai cara yang berbeda-beda berikut beberapa teori tentang kedaulatan di antaranya :
a. Kedaulatan Tuhan
b. Kedaulatan Negara
c. Kedaulatan Hukum, dan
d. Kedaulatan Rakyat

Ketiga elemen negara di atas yaitu masyrakat, wilayah dan pemerintahan dalam perkembangan sejarah mengalami beberapa perubahan dan tambahan di antaranya UUD (konstitusi) dan legitimasi internasional baik secara de fakto maupun de jure.

Negara terlepas dari ideologinya mempunyai beberapa fungsi yang mutlak, di antara fungsi tersebut yaitu :

a. Negara berfungsi sebagai stabilisator dalam mencapai tujuan bersama dan mencegah konflik-konflik dalam masyarakat serta melaksanakan penertiban (Law and Order).

b. Mengupayakan dan mengusahakan kesejahteraan serta kemakmuran seluruh rakyat yang berada dalam wilayah suatu negara.

c. Mempunyai pertahanan sebagai langkah antisipatif jika kemungkinan mendapat serangan dari luar.

d. Mempunyai badan-badan pengadilan sebagai bentuk menegakan keadilan untuk menciptakan masyrakat yang adil dan makmur.

Selain dari fungsi negara di atas Carles E. Merriam menyebutkan bahwa ada lima fungsi negara yaitu :

a. Pertama, keamanan ektern.

b. Kedua, ketertiban intern. 
c. Ketiga, keadilan.

d. Keempat, kesejahteraan umum.

e. Kelima, kebebasan.

Dari keseluruhan fungsi negara tersebut di atas dilaksanakan oleh pemerintah dalam rangka untuk menciptakan dan mencapai tujuan yang telah ditetapkan bersama. ${ }^{21}$

Tujuan Negara RI sebagai tercantum di dalam pembahasan Undang-Undang Dasar 1945 ialah: "untuk membentuk suatu pemerintahan Negara Indonesia melindungi segenap bangsa Indonesia dan seluruh tumpah darah Indonesia dan untuk memajukan kesejehteraan umum, mencerdaskan kehidupan bangsa dan ikut serta melaksasnakan ketertiban dunia yang berdasarkan kemerdekaan, perdamaian abadi dan keadilan social" denagn berdasar kepada: ketuhanan yang Maha Esa, kemanusiaan yang adil dan beradab, persatuan Indonesia, dan kerakyatan yang dipimpin oleh hikmah kebijaksanaan dalam permusyawaratan perwakilan serta dengan mewujudkan suatu keadilan social bagi seluruh rakyat Indonesia (Pancasila).

\section{Relevansi Agama Dengan Negara}

Dalam pendekatan sejarah, relasi antara agama Islam dengan negara dapat diklasifikasikan kedalam beberapa tipe. Tipe pertama, mengusahakan agar hubungan agama Islam dengan negara dapat terwujud secara harmonis melalui upaya pengintegrasian system, sebagai contoh dalam pengambilan suatu hokum baik agama Islam maupun negara sama-sama menjadi dasar utama sebagai pijakannya. Proses integrasi ini berjalan secara intensif pada kerajaan Islam seperti kerajaan samudra dan pasai di Aceh. Tipe kedua, antara agama dan negara mempunyai cara pandang masingmasing yang selanjutnya berimplikasi pada semua aspek kehidupan yang saling bertentangan satu sama lainya. Hal ini biasa terjadi karena sikap radikalis para agamawan untuk menerapkan peraturan agama secara totalitas, sedangkan pendekatan yang digunakan tidaklah sesuai dengan yang diharapkan masyarakat, fenomena ini pernah

${ }^{21}$ Ubaidillah. Pendidikan Kewarganegaraan: Demokrasi, HAM \& Masyarakat Madani, Jakarta: IAIN Press, 2000, hlm. 33-87 
tejadi di Sumatra Barat (Perang Paderi). Tipe ketiga, agama dan negara terjadi pola komunikasi yang searah sehingga tercipta kerukunan di dalalmnya, selain itu norma agama sedikit demi sedikit ikut serta mewarnai system hokum nasional. Salah satu daerah yang pernah menerapkan tipe ketiga ini adalah kerajaan Goa. Tipe keempat, adanya pengakuan ritual keagamaan di dalam masyarakat maksudnya praktek ritual yang diselenggarakan masyarakat turut serta dihadiri oleh Raja sebagai bentuk pengayoman kepada warganya. Raja memberikan kebebasan kepada warganya untuk memilih keyakinan yang diyakini tanpa menghilangkan kepatuhanya terhadap raja tersebut sebagaimana tradisi yang berlangsung di kerajaan Jawa.

Relasi agama dan negara setelah kemerdekaan Negara Republik Indonesia 17 Agustus 1945 menjadi perbincangan yang amat krusial diantaranya para tokoh pejuang bangsa yang mempunyai tafsir masing-masing akan relasi agama dan negara yang ideal, sehingga ada sebagian golongan yang berasumsi bahwa relasi agama dan negara yang ideal adalah sebagaimana yang sudah termaktub pada Piagam Jakarta. Selanjutnya melalui perdebatan itu lahirlah Ideology Pancasila yang secara subtansi isinya adalah bahwa negara Indonesia merupakan negara yang relegius. Negara secara nyata mengakui peran agama begitu juga sebaliknya agama tidaklah menolak eksistensi negara, sehingga antara agama dan negara mempunyai peran penting dalam mensukseskan kemerdekaan republic Indonesia dalam rangka menciptakan masyarakat yang adil dan makmur baldatun thoyyibatun warrabun ghofur dalam kerangka Negara Kesatuan Republik Indonesia.

Para ulama' sadar bahwa perjuangan negara bukanlah kepentingan pribadi melainkan kepentingan seluruh warga negara oleh sebab itu, dalam pelaksanaanya para ulama' lebih bersikap moderat dan tidak mementingkan kepentingan pribadi atau golongan tertentu. Hal ini semata demi mencapai kemaslahatan bersama tanpa harus membedakan ras, warna kulit, agama. Kesadaran ulama' akan pluralitas bangsa indonesia itulah yang kemudian melahirkan perumusan-perumusan ideology negara pancasila yang sekiranya dapat mengakomodir seluruh lapisan masyarakat yang ada. Dengan demikian Negara Kesatuan Republik Indonesia dan Pancasila sebagai dasar NKRI dianggap telah final, karena semua itu berangkat dan dibentuk melalui kultur dan semangat keagamaan masyarakat Indonesia. 
Dengan pendekatan fusngsional Al Ahkam yang menekankan pandangan rahmatan lil 'alamin, para ulama' mempunyai pandangan bahwa tujuan politik dalam norma agama tidak lain untuk melindungi hak-hak dasar manusia dan fungsi norma agama Islam yaitu mewujudkan kesejahteraan rakyat. Sedangkan Negara Kesatuan Republik Indonesia digunakan sebagai alat untuk menegakan syari'at agama. Disini dapat dipahami bahwa para ulama' lebih menekankan aspek subtansi dari nilai-nilai yang terkandung dalam dasar negara NKRI dibanding sekadar hanya agama dijadikan sebagai ajang formal (upaya islamisasi hanya dari luarnya saja belum sampai pada tahap internalisasi nilainilai keberagamaan). 


\section{Daftar Pustaka}

Abuddin Nata, Metodologi Study Islam, Jakarta : PT. Raja Grafindo Persada, 1999, cet. $\mathrm{Ke}-3$.

Budiyanto. Dasar-dasar Ilmu Tata Negara untuk SMU. Jakarta : Erlangga, 2000.

Dede Rosyada, Pendidikan Kewarganegaraan Demokrasi, HAM, dan Masyarakat Madani, Jakarta: IAN Jakarta Press, 2000.

Nasruddin Razak, Dienul Islam, Bandung : Al-Ma’arif, 1989.

Endang Saifuddin Anshari, Kuliah Al-Islam, Bandung : Pustaka, 1978.

Hammudah Abdalati, Islam in Focus, American Trust Publications Indianapolis-Indiana, 1975.

Harun Nasution, Islam Ditinjau dari Berbagai Aspeknya, Jilid I, Cetakan V, Jakarta: Penerbit Universitas Indonesia, 1985.

Humaedi Tata Pangarsa, Kuliah Akidah Lengkap, Surabaya: PT. Bina Ilmu, 1981, cet. ke5.

Ibrahim Gultom, Agama Malim Di Tanah Batak, PT.Bumi Aksara, Jakarta : 2010.

Jalaluddin Rakhmat, Psikologi Agama sebuah pengantar, Bandung: PT. MIizan Pustaka, 2004.

Miriam Budiarto, Dasar-dasar Ilmu politik, Jakarta: Gramedia Pustaka Media, 1978.

Tim Dosen Pendidikan Agama Islam MKDU UPI, 2008.

Ubaidillah. Pendidikan Kewarganegaraan: Demokrasi, HAM \& Masyarakat Madani, Jakarta: IAIN Press, 2000.

Aflatun Muchtar, Tunduk Kepada Allah Fungsi Dan Peran Agama Dalam Kehidupan Manusia, Jakarta : Khazanah Baru, 2001.

Software Kamus Besar Bahasa Indonesia, Version 1.5. 1 Offline

Sukardji, Agama-agama Yang Berkembang di Dunia dan Pemeluknya, Bandung: Angkasa, 1993.

Ubaedillah dan Abdul Rozak dkk, Pendidikan Kewarganegaraan, Demokrasi, HAM dan Masyarakat Madani, ICCE UIN Syarif Hidayatulla: Jakarta, Edisi ke-3, 2008. 